\title{
Risk of Agricultural Pesticide Exposure to Malaria Incidence and Anopheles Susceptibility at an Endemic Area in Central Java, Indonesia - A Case-control Study
}

\author{
Renti Mahkota ${ }^{1}$, Fajaria Nurcandra ${ }^{2 \star}$, Fitria Dewi Puspita Anggraini ${ }^{3}$, Annisa Ika Putri ${ }^{4}$, Bambang Wispriyono ${ }^{5}$ \\ ${ }^{1}$ Department of Epidemiology, Faculty of Public Health, Universitas Indonesia, Indonesia; ${ }^{2}$ Public Health, Faculty of Health \\ Science, Universitas Pembangunan Nasional Veteran Jakarta, Depok, Indonesia; ${ }^{3}$ Department of Entomology, Faculty of \\ Medicine, Public Health and Nursing, Universitas Gadjah Mada, Yogyakarta, Indonesia; ${ }^{4}$ Faculty of Science, Athena Institute \\ for Research on Innovation and Communication in Health and Life Sciences, Vrije Universiteit Amsterdam, Amsterdam, \\ Netherlands; ${ }^{5}$ Department of Environmental Health, Faculty of Public Health, Universitas Indonesia, Indonesia
}

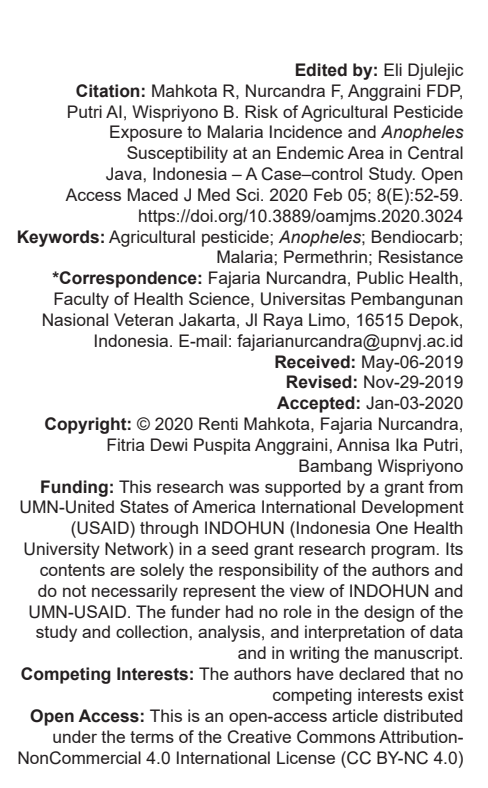

\section{Abstract}

BACKGROUND: Malaria is an infectious disease caused by Plasmodium sp. This disease often occurs in tropical countries and has sometimes been reported in agricultural countries. This vector-borne disease is associated with environmental factors and the presence of vectors. Some studies found that Anopheles is resistant to insecticide, and this topic was encouraged by the WHO for malaria control.

AIM: This research aimed to explain the causal effects of agricultural pesticide exposure on malaria incidence and Anopheles susceptibility in an endemic area of Indonesia.

METHODS: A case-control study was conducted between September and October 2016 in Purworejo, Centra Java. The case group involved 131 individuals who had malaria in 2016 based on their medical records, whereas the control group comprised 131 individuals who were neighbors of the cases and never had a history of malaria Cases were selected randomly from hospital medical records. Both case and control groups were interviewed using the same questionnaire, and data were analyzed using logistic regression. Insecticide susceptibility test was used to test the 80 mosquito samples collected from the neighborhood of recent malaria cases.

RESULTS: The quantity of agricultural pesticide remains a potential health risk to malaria (odds ratio $=2.15 ; 95 \%$ confidence interval 1.000-4.638), which was adjusted by confounders (sex, resting place, and insecticide net). The susceptibility test indicated that Anopheles was resistant to both permethrin (86.25\%) and bendiocarb $(68.75 \%)$.

CONCLUSIONS: The quantity of agricultural pesticide contributes as a risk factor to malaria incidences, and Anopheles was indicated to be resistant to bendiocarb in Purworejo, Central Java.

\section{Background}

The global prevalence of malaria and its significant health impact have made it a priority of vector-borne disease control. Malaria is one of the endemic vector-borne diseases in Indonesia [1]. In some cases, insecticide recommended by the local government has been indicated as not effective by the community. An eradication program has been initiated in some endemic areas, but the resistance is hampered. Rotation methods and accurate dosage of insecticide are implemented to avoid Anopheles resistance [1]. The most common control strategy is distributing pyrethroid impregnation bed-net and fogging the area where recent cases emerged. The fogging is done to control the population of adult mosquito around a radius of $100 \mathrm{~m}$ of the case area with two cycles at 1-week intervals. On the other hand, the household and agricultural insecticides used by the community in and around the neighborhood insecticides can affect the mosquitoes [2]. Agricultural insecticides play a role in mosquito resistance because mosquito breeding areas are directly exposed to insecticides and its residual [1].

Organophosphates, organochlorines, and carbamates, which are known as agricultural pesticides, are harmful to human health. Pyrethroid is one of the chemical substances used in agricultural pesticide sprayers to control insects [3]. Anopheles gambiae uses agricultural land as a breeding area. The frequent pesticide exposure can lead to resistance in Anopheles. Research in Benin showed $A$. gambiae resistant to 
dichlorodiphenyltrichloroethane and pyrethroid [4]. This finding aligns with a study in a region of Parakuo, which found that $82.2 \%$ of $A$. gambiae samples have mutated [4]. Other studies also proved that1014S KDR allele exists in a wild Anopheles arabiensis population in Benin and West Africa. Another study found that there is resistance to five insecticides in Khartoum, including pyrethroid which is recommended by the $\mathrm{WHO}$. The increase of resistance on the pesticides may correlate to KDR L1014F allele [5].

Malaria is an infectious disease caused by Plasmodium sp. and often occurs in tropical countries [6]. Malaria is associated with environmental factors and the presence of vectors. This illness causes economic burden, especially in an endemic area [7]. Indonesian Malaria program aspires to eliminate malaria by 2030. From 2011 to 2015, the annual parasite incidence (API) in Indonesia has declined each year. Based on the Indonesia Malaria Report 2015, API in Central Java was the highest in Java Island in which the highest cases are in Purworejo, with approximately 1000 malaria cases every year [8]. District Health Office Reported 6 out of 16 subdistricts in Purworejo are the endemic areas [9].

About $69 \%$ of the total population in Purworejo are farmers. This condition sets a high potential for agricultural insecticide use [10]. However, the amount is not in line with good knowledge of the risk of pesticide use [11]. Pesticides, as an environmental hazard, affect the health of individuals, populations, and balance of the ecosystem. Purworejo, Menoreh Hills, in particular, has been known as an endemic malaria area in Central Java [7]. We predicted that pesticide exposure would be a contributing factor for the endemicity of malaria in the area. Interventions for malaria can be conducted through surveillance, vector control, sanitation, and monitoring the molecular basis of the vectors and their agent [12]. To the best of our knowledge, no studies about the effect of Anopheles resistance to insecticide on malaria incidence in an endemic area of Indonesia, especially in an endemic area, have been conducted yet. This research aimed to explain the effects of agricultural pesticide exposure on malaria incidence and Anopheles susceptibility in an endemic area of Indonesia.

\section{Methods}

A case-control study was conducted from April to November 2016. A pilot study had been conducted to test the validity and reliability of the questionnaire. Twenty samples, residing in Purworejo in 2016, were interviewed to assess the case status and the distribution of exposure. The case group was malaria patients who were recruited based on hospital and primary health-care center medical records. The control was healthy people residing in the neighborhood. All cases were selected randomly based on medical records. Inclusion criteria for the cases were residents since 2015 who aged between 12 and 75 years old. The inclusion criteria for the controls were people who never contracted with malaria in their lifetime. The exclusion criteria for both groups were pregnant women, suffering severe disease, $>75$ years old, people with a disability, and those who did not consent to participate. Interviews were done after consent has been obtained. We collected 276 questionnaires from the interview. Data were collected from September to October 2016 by ten graduates of a health science program.

According to the geographical characteristics, the area of the case was close to plantations and rice fields. A unique characteristic of the subjects is they live nearby the rice fields or plantations. The exposure of agricultural insecticides in mosquito breeding places has been reported as a cause of Anopheles resistance. Agricultural insecticide exposure was defined as the average volume of insecticide used per year. The average volume expresses in units/year in the last 5 years, where 1 unit is equal to $1 \mathrm{~L}$.

The Chi-square test was performed to analyze potential variables for multivariate analysis, and logistic regression was performed to determine the best model. We predicted that the result would indicate the true value of associations between agricultural pesticide exposure and malaria incidence after controlling the confounding variables.

Adult mosquitoes were collected from 21 to 22 October 2016 in two villages (Turus Wetan and Plipir) during extreme weather with a high density of rain. Those villages were selected because there was a high increase in malaria cases, but prevention efforts have not been made in these villages. The mosquito sampling locations were selected based on the characteristics of the residential area where the current malaria cases were detected. The sampling locations were also determined based on the suggestions of Purworejo District Health Office. Adult mosquito sampling was surveyed using the human decoy method. The adult mosquitoes were collected at indoor, outdoor, and shelter. Indoor mosquito sampling was focused on resting places such as hanging clothes and walls. The mosquitoes were caught using an aspirator between 18:00 and 06:00. In all, four catching points in these villages included a cattle pen near the residential area, bushes around the two cattle pens, and a rice field nearby the cattle pen. The mosquitoes were caught using a mosquito net. The majority of the house walls in this area are made of bamboo or semi-permanent with many holes for mosquitoes' entrance. The existence of breeding places was confirmed by observations around the case and control house in a radius of $50 \mathrm{~m}$. The observations also confirmed that larvae and its predators were found in those potential breeding places. After that, the collected adult mosquitoes were tested using insecticide susceptibility tests. A susceptible strain of Anopheles maculatus was used as a reference strain for bioassays and biochemical studies at the Laboratory of the Department of Parasitology, Gadjah Mada University. 
The susceptibility tests were done to check the mosquito resistance to insecticides. The type of insecticide used in the experiment was often utilized for vector-control programs, agriculture pesticides, and household insecticides in Purworejo [13]. Insecticide susceptibility test-kits and the WHO standard procedures 2016 were used to monitor the susceptibility of wild $A$. maculatus populations on two groups of insecticide exposures, which are commonly used in agriculture. A. maculatus mosquitoes were initially identified based on their morphology before the bioassays test was performed. Eighty mosquitoes were divided into four tubes in each test. Of those, 20 mosquitoes were unexposed for an hour. Each tube was exposed to impregnated papers with $0.1 \%$ bendiocarb and $0.75 \%$ permethrin. Mosquitoes were first exposed to permethrin. Subsequently, they were exposed to bendiocarb, as described above. The mosquitoes' mortality was recorded $24 \mathrm{~h}$ after the exposure. The WHO has classified $<90 \%$ of observed mortality as resistance, $90-97 \%$ of mortality rates as tolerant, and $98-100 \%$ as susceptible to mortality [14].

\section{Results}

Data were obtained from 276 questionnaires. Fourteen questionnaires were excluded because of missing data and fail to meet the inclusion criteria. In all, seven cases and seven controls were excluded. Distribution and proportion of each variable based on receiver operating characteristic (ROC) of the cutoff point(Tables 1 and 2).

The proportion of agricultural pesticide use was higher in the case group than the controls (Table 1). Agricultural pesticide use per year among the cases was higher than the controls by $\geq 0.25$ units/year. About 114 people $(87.02 \%)$ of the cases and 105 people $(80.15 \%)$

Table 1: Agricultural pesticide exposure and socio-demographic characteristics of participants

\begin{tabular}{|c|c|c|c|c|c|}
\hline \multirow[t]{2}{*}{ Variable } & \multicolumn{2}{|c|}{ Malaria } & \multirow[t]{2}{*}{ Total } & \multirow[t]{2}{*}{$p$ value } & \multirow[t]{2}{*}{ OR crude $(95 \% \mathrm{Cl})$} \\
\hline & Case & Control & & & \\
\hline \multicolumn{6}{|l|}{ Agricultural Pesticides } \\
\hline$\geq 0.25$ unit/year & $114(87.02 \%)$ & $105(80.15 \%)$ & 219 (83.59\%) & \multirow{2}{*}{0.133} & $1.66(0.81-3.45)$ \\
\hline$<0.25$ unit/year & $17(12.98 \%)$ & $26(19.85 \%)$ & $43(16.41 \%)$ & & \\
\hline \multicolumn{6}{|l|}{ Age } \\
\hline$<29$ & $61(46.56 \%)$ & 66 (50.38\%) & $127(48.47 \%)$ & \multirow{3}{*}{0.412} & 1 \\
\hline $29-39$ & $34(25.95 \%)$ & $35(26.72 \%)$ & $69(26.34 \%)$ & & $0.81(0.41-1.60)$ \\
\hline$>39$ & $36(27.48 \%)$ & $30(22.90 \%)$ & $66(25.19 \%)$ & & $0.77(0.42-1.40)$ \\
\hline \multicolumn{6}{|l|}{ Gender } \\
\hline Male & $59(45.04 \%)$ & $38(29.01 \%)$ & $97(37.02 \%)$ & \multirow{2}{*}{0.007} & \multirow{2}{*}{$2.00(1.17-3.46)$} \\
\hline Female & $72(54.96 \%)$ & 93 (70.99\%) & $165(62.98 \%)$ & & \\
\hline \multicolumn{6}{|l|}{ Educational Level } \\
\hline ZJunior High School & $68(51.91 \%)$ & $58(44.27 \%)$ & $126(48.09 \%)$ & \multirow{2}{*}{0.216} & \multirow{2}{*}{$1.36(0.81-2.27)$} \\
\hline < Junior High School & $63(48.09 \%)$ & $73(55.73 \%)$ & $136(51.91 \%)$ & & \\
\hline \multicolumn{6}{|l|}{ Period of Residency } \\
\hline$<19$ year & $61(46.56 \%)$ & $68(51.91 \%)$ & $129(49.24 \%)$ & \multirow{3}{*}{0.413} & 1 \\
\hline 19-34 year & $35(26.72 \%)$ & $32(26.72 \%)$ & $67(25.57 \%)$ & & $1.22(0.67-2.21)$ \\
\hline$>34$ year & $35(26.72 \%)$ & $31(23.66 \%)$ & $66(25.19 \%)$ & & $1.26(0.69-2.28)$ \\
\hline \multicolumn{6}{|l|}{ BMI } \\
\hline$<21.60$ & $74(56.49 \%)$ & $59(45.04 \%)$ & $133(50.76 \%)$ & \multirow{2}{*}{0.064} & \multirow{2}{*}{$1.58(0.94-2.66)$} \\
\hline$\geq 21.60$ & $57(43.51 \%)$ & $72(54.96 \%)$ & $129(49.24 \%)$ & & \\
\hline \multicolumn{6}{|l|}{ Occupation } \\
\hline High risk & $76(58.02 \%)$ & 77 (58.78\%) & $153(58.40 \%)$ & \multirow{2}{*}{0.900} & \multirow{2}{*}{$0.97(0.57-1.63)$} \\
\hline Low risk & $55(41.98 \%)$ & $54(41.22 \%)$ & $109(41.60 \%)$ & & \\
\hline
\end{tabular}

Table 2: Behavioral and environmental factors of malaria incidence

\begin{tabular}{|c|c|c|c|c|c|}
\hline \multirow[t]{2}{*}{ Variable } & \multicolumn{2}{|c|}{ Malaria } & \multirow[t]{2}{*}{ Total } & \multirow[t]{2}{*}{$\mathrm{p}$ value } & \multirow[t]{2}{*}{ OR crude $(95 \% \mathrm{Cl})$} \\
\hline & Case & Control & & & \\
\hline \multicolumn{6}{|c|}{ Existence of Mosquito Resting Place around the Residential Area } \\
\hline Yes & $16(12.21 \%)$ & $13(9.92 \%)$ & $29(11.07 \%)$ & \multirow{2}{*}{0.555} & \multirow{2}{*}{$1.26(0.54-2.99)$} \\
\hline No & $115(87.79 \%)$ & $118(90.08 \%)$ & $233(88.93 \%)$ & & \\
\hline \multicolumn{6}{|c|}{ Existence of Mosquito Breeding Place around the Residential Area } \\
\hline Yes & $41(31.30 \%)$ & $42(32.06 \%)$ & $83(31.68 \%)$ & \multirow{2}{*}{0.894} & \multirow{2}{*}{$0.96(0.55-1.68)$} \\
\hline No & $90(68.70 \%)$ & $89(67.94 \%)$ & $179(68.32 \%)$ & & \\
\hline \multicolumn{6}{|c|}{ Having Livestock } \\
\hline Yes & $76(58.02 \%)$ & $76(58.02 \%)$ & $152(58.02 \%)$ & \multirow[t]{2}{*}{1.000} & \multirow[t]{2}{*}{$1(0.59-1.68)$} \\
\hline No & $55(41.98 \%)$ & $55(41.98 \%)$ & $110(41.98 \%)$ & & \\
\hline \multicolumn{6}{|c|}{ Presence of Mosquito's predator } \\
\hline Yes & $106(80.92 \%)$ & $105(80.15 \%)$ & $211(80.53 \%)$ & \multirow[t]{2}{*}{0.876} & \multirow[t]{2}{*}{$1.05(0.54-2.02)$} \\
\hline No & $25(19.08 \%)$ & $26(19.85 \%)$ & $51(19.47 \%)$ & & \\
\hline \multicolumn{6}{|c|}{ House Cleaning Habit } \\
\hline Bad & $115(87.79 \%)$ & $107(81.68 \%)$ & $222(84.73 \%)$ & \multirow[t]{2}{*}{0.169} & \multirow[t]{2}{*}{$1.61(0.77-3.34)$} \\
\hline Good & $16(12.21 \%)$ & $24(18.32 \%)$ & $40(15.27 \%)$ & & \\
\hline \multicolumn{6}{|c|}{ Use of Insecticide net } \\
\hline No & $86(65.65 \%)$ & $120(91.60 \%)$ & $206(78.63 \%)$ & \multirow[t]{2}{*}{$<0.001$} & \multirow[t]{2}{*}{$0.17(0.08-0.37)$} \\
\hline Yes & $45(34.35 \%)$ & $11(8.40 \%)$ & $56(21.37 \%)$ & & \\
\hline \multicolumn{6}{|c|}{ Night Outdoor Activity } \\
\hline Yes & $42(32.06 \%)$ & $34(25.95 \%)$ & 76 (29.01\%) & \multirow[t]{2}{*}{0.276} & \multirow[t]{2}{*}{$1.35(0.76-2.39)$} \\
\hline No & 89 (67.94\%) & 97 (74.05\%) & $186(70.99 \%)$ & & \\
\hline \multicolumn{6}{|c|}{ Repellent use } \\
\hline No & $37(28.24 \%)$ & $28(21.37 \%)$ & $65(24.81 \%)$ & \multirow[t]{2}{*}{0.198} & \multirow[t]{2}{*}{$1.45(0.79-2.66)$} \\
\hline Yes & $94(71.76 \%)$ & $103(78.63 \%)$ & $197(75.19 \%)$ & & \\
\hline \multicolumn{6}{|c|}{ Wearing Long Cloth during Outdoor Activities } \\
\hline No & $20(15.27 \%)$ & $11(8.40 \%)$ & $31(11.83 \%)$ & \multirow[t]{2}{*}{0.085} & \multirow{2}{*}{$1.96(0.85-4.75)$} \\
\hline Yes & $111(84.73 \%)$ & $120(91.60 \%)$ & $231(88.17 \%)$ & & \\
\hline
\end{tabular}


of the controls used pesticides as much as $\geq 0.25$ units/ year. The Chi-square test obtained $p=0.133$, which means that no significant relationship exists between the quantity of agricultural pesticide use and malaria. People using pesticides $\geq 0.25$ units/year have 1.66 higher odds to contract malaria (95\% confidence interval [Cl] 0.813.45). Specifically, we found a unique variable that may play a role as a contributing factor in malaria incidence. The variable body mass index $(\mathrm{BMI})<21.60$ was found as a risk factor, if we assessed by crude odds ratio (OR).

Table 3 shows the results of multiple logistic regression. The table reveals that confounding variables significantly affected the number of agricultural pesticide use on malaria incidence. The quantity of agricultural pesticides has a significant $p$-value, which is 0.050 (OR $=2.15 ; 95 \% \mathrm{Cl} 1.000-4.638$ ), after being controlled by the potential confounders (sex, resting place, and insecticide net). It means that people who use agricultural pesticides at $\geq 0.25$ units/year had 2.15 times higher odds to contract malaria compared with those who use pesticides at $<0.25$ units/year.

Table 3: Association between Agriculture Pesticides and Malaria Incidence

\begin{tabular}{lccccc}
\hline Variable & Std. & $\mathrm{p}$ & AdjOR & \multicolumn{2}{c}{$95 \% \mathrm{Cl}$} \\
\cline { 6 - 7 } & Error & value & & Lower & Upper \\
\hline Agricultural Pesticide $\geq 0.25$ unit/year & 0.84 & 0.050 & 2.15 & 1.000 & 4.638 \\
Male Gender & 0.55 & 0.015 & 1.96 & 1.139 & 3.391 \\
Resting Place Existence & 0.88 & 0.147 & 1.94 & 0.793 & 4.723 \\
No insecticide net & 0.06 & 0.000 & 0.18 & 0.085 & 0.367 \\
\hline
\end{tabular}

Potential breeding places for Anopheles were found around the case and control group. Several people who live around the cases' house worked as brown sugar makers. We found that abandon bamboo containers that were used by the brown sugar makers have become breeding places of Anopheles. In addition, other common breeding places found were natural puddles and open household wastewater. Typical Anopheles resting place at this location is bushes from plantations and rice fields. Based on observations, the types of walls found in most subjects are walls, wood, and bamboo (Figure 1a-e).

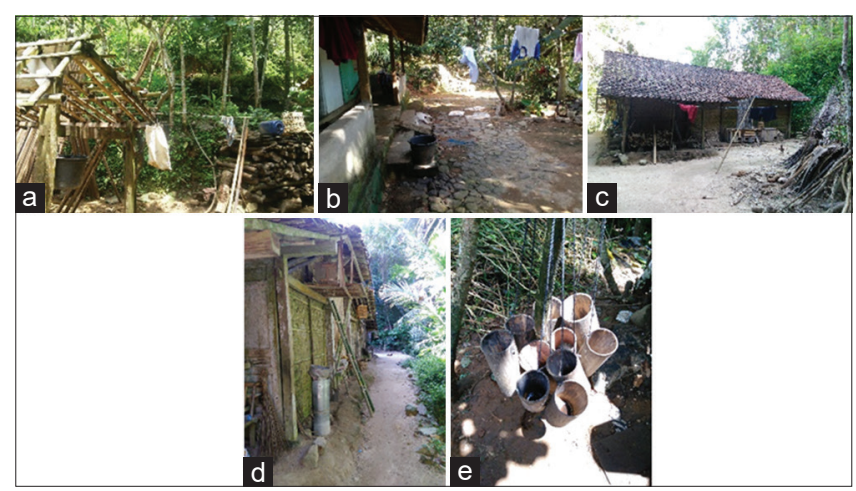

Figure 1: (a-e) Observation result of environmental condition around the study site

\section{Mosquito collection}

We collected Culex quinquefasciatus, Culex tritaeniorhynchus, Culex vishnui, Culex gelidus, and Armigeres in the first house. Of these, male C. quinquefasciatus was the most common type. In an outdoor resting place, $94 \%$ of Culex sp. were found.

The second house exhibited the Culex genus. The comparison of the number of mosquitoes between indoor and outdoor resting was 5:7. C. quinquefasciatus dominated both indoor and outdoor resting. For indoor resting, $100 \%$ of mosquitoes caught were female. It happened because of the mosquito biting behavior. Most female mosquitoes need blood intake for egg cell maturation. Indoor resting provided more opportunities for the Culex mosquito to obtain greater blood intake.

The third house provided a varied mosquito to be caught. We collected Anopheles, Culex, and Armigeres indoors. Approximately $85.7 \%$ of the collected mosquitoes still dominated by females Anopheles starts to be around at 10:00 pm; this was expected because rainwater droplets had entirely dried up. Anopheles has fragile wings when it comes out shortly after the rain stops.

\section{Permethrin susceptibility test}

Some mosquitoes remained alive at a longer observation interval after experiencing a knockdown. The percentage of living mosquitoes on $60 \mathrm{~min}$ observation was equal to $65 \%$. After $24 \mathrm{~h}$, the observed mortality could be shown using the equation below. The susceptibility test using permethrin indicated that Anopheles was resistant.

$$
\begin{aligned}
\text { Observedmortality } & =\frac{\text { Totalnumber of deadmosquitoes }}{\text { Total sample size }} \times 100 \\
& =\frac{69}{80} \times 100=86.25 \%
\end{aligned}
$$

\section{Bendiocarb susceptibility test}

Mosquitoes revived at a longer observation interval, after being exposed to permethrin and experiencing a knockdown. In the early minutes of observation, the mosquito knockdown level was higher when exposed to bendiocarb than other insecticides. However, the final percentage of knockdown mosquitoes using bendiocarb exposure was much lower than when using permethrin (33.75\%). The result indicated that Anopheles was also resistant to bendiocarb.

$$
\text { Observedmortality }=\frac{\text { Totalnumber of deadmosquitoes }}{\text { Total sample size }} \times 100
$$

$$
=\frac{55}{80} \times 100=68.75 \%
$$




\section{Discussion}

Based on the cutoff point ( 0.25 units/year), the quantity of pesticide used per year in the case group was higher ( $\geq 0.25$ unit/year or at-risk category) than the control group. The relationship between the use of pesticide and malaria was quite strong, which indicated by $\mathrm{OR}=2.151(95 \% \mathrm{Cl} 1.000-4.638)$ after being controlled by the potential confounders (sex, resting place, and insecticide net). This result meant that people using agricultural pesticides at-risk category would have 2.15 higher odds to contract malaria compared with those who use the pesticides at $<0.25$ unit/year.

Anopheles around the agriculture or plantation areas may have built resistance. This phenomenon impacts the difficulty of controlling Anopheles from biting humans around the area. Agricultural insecticide also directly impacts larvae breeding places and its residual. This condition impacted the development of larvae as an insecticide-resistant adult mosquito [1]. As a result, Anopheles still survives even when humans use indoor insecticide. We found that people only used insecticidetreated nets (ITNs) after they contracted malaria, and most of them received ITN from Pusat Kesehatan Masyarakat (Primary healthcare center) (Puskesmas). It occasionally occurred in a case-control study where the cases tend to remember the exposure better. Case groups had a high awareness level of protection to avoid the same illness [15]. The cutoff point for BMI of this study was 21.6. BMI, which below the cutoff point, is a possible risk factor. In this study, there was no significant association between BMI and malaria incidence. This might be caused by an inaccurate classification and the lack of a sample. However, the previous research reinforces the finding that a low BMl was found to increase the risk of malaria. Good nutritional status is very important as prevention of infectious diseases, malaria in particular [16]. Another contrast study reported that obesity is strongly associated with single severe malaria as well as interactions with other factors such as hypertension, dyslipidemia, or diabetes [17].

The use of insecticides in agriculture has been correlated to the resistance in malaria vectors [18]. The results were consistent with studies from other countries. Organophosphates, carbamates, permethrin, and bendiocarb were the most common pesticides in agriculture. Bendiocarb is a type of pesticide with the highest levels of mosquito resistance found particularly in peri-urban sites [5]. Based on the previous studies, the most common brand of pesticides used in Purworejo was Fastac, Dasinon, Danke. The local farmers did not use the pesticide at an appropriate dose [11], [19]. Fastac, which contains permethrin, is widely used in Purworejo to control insects. It suppresses a vast selection of mosquito larval populations, which has resulted in the emergence of insecticide resistance in malaria vectors [20].

According to 23 of 25 relevant publications across Africa, a higher resistance in mosquito populations was associated with the use of agricultural insecticides. Insecticide resistance occurs due to physiological and behavioral changes in population levels that are shifted by continuous environmental exposures of insecticides or other chemical hazards over time. The agriculture insecticides contaminated the vectors through the nearby breeding sites. It would be challenging to delineate the effect of early exposure to adult resistance in vivo [21], [22]. In this case, the study location in Purworejo was close to natural habitats (breed site and resting site) of Anopheles like a local plantation, rice field, and springs, which have potential exposure to agricultural insecticide.

Water is essential for mosquitoes to breed. Mosquitoes could not survive in arid deserted countries, but wells and irrigation have allowed mosquitoes to breed. In general, rainfall increases the number of breeding places for mosquitoes. Thus, more malaria incidence occurs during the wet season. However, heavy rain-washed outbreeding places could decrease the mosquito population [23].

A few numbers of Anopheles were collected from the site because of the heavy rainfall between 4 PM and 10 PM. It occurred probably due to Anopheles' characteristic, which they are easily blown in windy weather, which might decrease their biting behavior during those times. Anopheles are nocturnal mosquitoes which sensitive to the light. It caused Anopheles to appear in the location after midnight. Besides, Anopheles' wings are thinner than the Aedes and Culex genus. They are more fragile after the rain [24]. It explained why this study only collected a few numbers of Anopheles.

The susceptibility test showed that Anopheles in Purworejo were resistant to permethrin and bendiocarb. This resistance was caused by the evolution of a selected insecticide after daily basis use. One of the contributing factors for resistance is the level of pressure received by a population of insects/vectors. Under the same conditions, one population with a higher pressure of insecticide will develop resistance over a shorter time than an insect population, which receives a low pressure of insecticides. This Anopheles can have single, double (multiple), or cross-resistance to insecticides. Insecticide resistance develops after a selection process that has been lasting for many generations in their agricultural breeding site. Resistance can be caused by genetic, biological, and operational (use of insecticides by setting) factors. Genetic factors consist of frequency, number, and dominance of resistant alleles. Biological factors include biological behavior, the ecology of insects, and the number of generations per year, mobility, and migration. Operational factors comprise the type and nature of insecticides use, history of insecticides used, intensity and frequency of use, target stage, dosage, means of applications, and formulations of the insecticides composition [25], [26]. In this study, Anopheles resistance is probably in genetic and biological factors. The behavioral factors played a dominant role because of the ineffectiveness of environmental controls at breeding and resting places. The ineffective control is 
probably due to wide habitats of Anopheles at the study location, which is the natural forest of hills.

Carbamate is known as methylcarbamate and is derived from methylcarbamic acid. The compounds are used as insecticides, nematicides, and acaricides. They have low environmental persistence and are less toxic to living organisms than organochlorine. However, they can be found in food, water, and air contaminant agents with adverse effects on humans and other animals because the substances are widely used in agriculture also in Purworejo. Around 1970, synthetic pyrethroid was released and considered a more efficient and less toxic insecticide. These insecticides gained more attention by presenting a higher lethal capacity against insects while requiring smaller doses for satisfactory results. Consequently, all pyrethroids were substituted or supplemented with the use of other classes of pest control in many areas. It represented nearly $23 \%$ of the chemical insecticides market, namely, than one-fourth of the world market [27].

Pyrethroids are synthetic analogs of chrysanthemic acid (Pyrethrins I) and pyrethric acid (Pyrethrins II) ester insecticides. It naturally occurs in the leaves of Chrysanthemum cinerariifolium and has been chemically distinguished as Type I (lacking an alpha-cyano group, like permethrin) and Type 2 (an alpha-cyano group, like deltamethrin). Both compounds are biodegradable, noncumulative insecticides that rarely cause acute intoxication among birds and mammals. Currently, malaria control depends on this insecticide class, which has been widely employed in indoor residual spraying (IRS) and to control agricultural pests worldwide. Furthermore, pyrethroid is the only class approved by the WHO Pesticide Evaluation Scheme for mosquito net impregnation (ITN; longlasting ITN) [21], [28], [29], [30]. IRS is a method in which residual insecticides are applied on the surface of walls and ceilings of houses. Based on this strategy, the mosquitoes were expected to rest on surfaces after taking blood. Werner reviewed that this moment is long enough to absorb a lethal dose of the insecticide. ITN is a mosquito net that repels, incapacitates, or kills mosquitoes that come into contact with the impregnated insecticide in the net material, and both a chemical and a physical barrier against insects [31].

This study found that Anopheles were resistant to both permethrin and bendiocarb. This resistance may be caused by permethrin of agricultural insecticide beside from IRS and/or ITN. Based on the results of B2P2VRP evaluation survey of mosquito nets, the use of the insecticide is still effective for killing malaria mosquitoes in 1 and 3 months. Several contributors to the effectiveness of mosquito nets include community behavior in the process of washing and drying mosquito nets [13]. Based on our observation, the subject's ITN from Puskesmas was no longer used because it had been damaged. Furthermore, subjects said that they felt uncomfortable using ITN.
Synthetic pyrethroid and bendiocarb insecticide are commonly applied in IRS as malaria control efforts [32]. Anopheles is rarely exposed to carbamate insecticides because it is often applied in the plantation areas during daylight, but our result showed that a probability of resistance to permethrin in Fastac. This exposure could happen when the larvae of Anopheles breed around plantations and rice fields. However, the mechanism of resistance occurring from the second class of insecticides still requires further research. There is a probability that Anopheles resistance due to exposure of insecticide of IRS or ITN or agricultural during their larval phase in the agriculture site. We predict that bendiocarb exposure from IRS application in controlling Anopheles. However, bendiocarb was found ineffective in killing this species. Hence, the IRS application is better using organophosphate insecticides. The accuracy of the dosage and type of insecticide can influence the effectiveness of vector control. These were sometimes never considered by local farmers [13].

The mechanism of Anopheles resistance to permethrin and bendiocarb in this study comprised three types of biochemical basis. The first was target-site resistance that occurred when insecticides can no longer bind targets. The second was detoxification enzyme-based resistance because of an increase in enzyme esterase, oxidase, or glutathioneS-transferase activity to degrading the insecticides before reaching the target site. Third, early detection of Anopheles' susceptibility status to insecticides can be useful as information to select the most appropriate insecticides for specific local vector control. Detecting Anopheles resistance to insecticides can be conducted using several ways, namely, conventional detection (based on the WHO susceptibility test standard using impregnated paper) [33], [34]. However, this mechanism of Anopheles in Purworejo needs to be confirmed.

This case-control study required respondents to identify the risk factors of malaria in the endemic area. Meanwhile, Anopheles mosquitoes in the neighborhood were collected and tested using the insecticide susceptibility test. The control group was intended to avoid misclassification between disease status and other contributing factors of malaria occurrence. This study design had several limitations, such as the possibility of other existing variables, such as confounders that were not measured in this study. Some variables were less significant to express any relationship between the independent and dependent variables because the majority of variables that were ranging the $95 \% \mathrm{Cl}$ passed a null value, or the sample size was insufficient to show any relationship [35]. Recall bias possibly occurred against the independent variable and other extraneous variables that happened previously. The possibility of shared exposure to environmental factors between the case and control groups might have caused an obscure difference among the risk factors. Another limitation was determining the standard score and the threshold value 
for the number of pesticides used. Some other variables were recorded using a cutoff point value of ROC in the univariate analysis. Scoring and categorization were relative to describe the conditions of the study population and may have differed from other populations. Any bias may have underestimated the misclassification of nondifferential points among the results.

A misclassification may have occurred due to an equal position between the cases and the controls [15]. Furthermore, the number of cases was based on health-care centers' medical records and data registers in Purworejo. The number could have possibly been underestimated because only those with severe malaria conditions seek health services. Most of the closest neighbors of the cases also acquired malaria, as was proven in the field. This condition complicated the process of selecting the control group. Another limitation of this study is we did not consider interviewing the history of IRS as possible exposure to bendiocarb and permethrin. This study only detected mosquito resistance to bendiocarb, which may originate from the IRS during malaria control from the government.

\section{Conclusions}

We found that the proportion of malaria was higher on men with low education backgrounds, had lower BMI, had mosquito resting places around the house, had bad house cleaning habits, using an insecticide-bed net, doing night activities, and did not use of repellant and did not wear long cloth. The agricultural pesticide quantity remains a potential health risk of malaria after adjusting the confounders (sex, resting place, and insecticide net). Anopheles in Purworejo was probably resistant to both permethrin and bendiocarb. For further research, we suggest considering to include the history of IRS each subject to determine whether the Anopheles resistance due to bendiocarb and permethrin exposure of IRS or agricultural insecticide.

\section{Availability of data and materials}

The datasets used and/or analyzed during the current study are available from the corresponding author on reasonable request.

\section{Authors' Contributions}

RM, FN, FDPA, AIP, and BW are involved in conceptualizing and designing the study. RM, FN, FDPA, and AIP searched the literature. RM, FN, and FDPA prepared the questionnaire and collected the data. RM dan FN analyzed the data and prepared the manuscript. RM, AIP, and BW reviewed the manuscript. All authors read and approved the final manuscript.

\section{Ethics Approval and Consent to Participate}

Ethics approval was obtained from the Ethics Commission of Research and Community Service, Faculty of Public Health, Universitas Indonesia, Jakarta, Indonesia (258/H2.F10/PPM.00.02/2016). Written informed consent was obtained from the subject of the case and control group for voluntary participation.

\section{Acknowledgments}

The authors would like to thank Indonesia One Health University Network (INDOHUN) for fully funded this study, Dr. Tri Yunis Miko (Head of Department of Epidemiology Faculty of Public Health Universitas Indonesia), Government of Purworejo, District Health Office, Tjitrowardojo Hospital for the case information dataset and their assistance during the data collection process.

\section{References}

1. Chang X, Zhong D, Fang Q, Hartsel J, Zhou G, Shi L, et al Multiple resistances and complex mechanisms of Anopheles sinensis mosquito: A major obstacle to mosquito-borne diseases control and elimination in China. PLoS Negl Trop Dis. 2014;8(5):e2889. https://doi.org/10.1371/journal.pntd.0002889 PMid:24852174

2. Widiarti W, Boewono DT, Garjito TA, Tunjungsari R, Asih PB, Syafrudin D. Identification of dot mutations in "Gene Voltage Gated Sodium Channel" Aedes aegypti resistancy to pyrethroid insecticide in Semarang, Central Java. Bul Penelit Kesehat. 2012;40(1):31-7.

3. Kapka-Skrzypczak L, Cyranka M, Skrzypczak M, Kruszewski M. Biomonitoring and biomarkers of organophosphate pesticides exposure-state of the art.AnnAgric Environ Med. 2011(2);18:294-303. PMid:22216802

4. Djègbè I, Boussari $O$, Sidick $A$, Martin $T$, Ranson $H$, Chandre $F$, et al. Dynamics of insecticide resistance in malaria vectors in Benin: First evidence of the presence of L1014S kdr mutation in Anopheles gambiae from West Africa. Malar J. 2011;10:261. https://doi.org/10.1186/1475-2875-10-261 PMid:21910856

5. Abuelmaali SA, Elaagip AH, Basheer MA, Frah EA, Ahmed FT, Elhaj HF, et al. Impacts of agricultural practices on insecticide resistance in the malaria vector Anopheles arabiensis in Khartoum State, Sudan. PLoS One. 2013;8(12):e80549 
https://doi.org/10.1371/journal.pone.0080549

PMid:24260414

6. CDC and Zoonotic Disease. Available from: http://www.cdc.gov/about facts/cdcfastfacts/zoonotic.html. [Last accessed on 2016 Apr 23].

7. Murhandarwati EE, Fuad A, Sulistyawati, Wijayanti MA, Bia MB, Widartono BS, et al. Change of strategy is required for malaria elimination: A case study in Purworejo district, central java province, Indonesia. Malar J. 2015;14:318. https://doi. org/10.1186/s12936-015-0828-7

PMid:26275822

8. Ministry of Health Republic Indonesia. InfoDatin Malaria Indonesia: Ministry of Health Republic Indonesia; 2016. p. 7.

9. Heksantoro R. Purworejo Endemik Malaria Tertinggi se Jawa. Detiknews. Available from: https://www.news.detik.com/beritajawa-tengah/d-3622133/purworejo-endemik-malaria-tertinggise-jawa. [Last accessed on 2016 Apr 23]

10. BPS Provinsi Jawa Tengah. H Asil S Ensus P Ertanian. 2013 (Angka Tetap) 2013;2015.

11. Nurcandra F, Mahkota R, Shivalli $S$. Effect of personal protective equipment during pesticide application to neurological symptoms in farmers in Purworejo district, Indonesia. Kesmas J Kesehat Masy Nas. 2018;12(4):165-71. https://doi.org/10.21109/kesmas.v12i4.1695

12. One Health Initiative. Available from: http://www.onehealthinitiative. com/about.php. [Last accessed on 2016 May 20].

13. Setiyaningsih R, Trapsilowati $\mathrm{W}$, Mujiyono M, Lasmiati L. Pengendalian vektor malaria di daerah endemis kabupaten Purworejo, Indonesia. BALABA. 2018;14(1):1-12. https://doi. org/10.22435/blb.v14i1.290

14. World Health Organization. Supplies for Monitoring Insecticide Resistance. Geneva: World Health Organization; 2002. p. 1-16.

15. Elwood M. Critical Appraisal of Epidemiological Studies and Clinical Trials. $3^{\text {rd }}$ ed. Vancouver, New York: Oxford University Press Inc.; 2007.

16. Godana I, Baker L, Wisely A. The impact of nutrition and body mass index on malaria in rural western Kenya. J Chem Inf Mod. 2019;53(9):1689-99.

17. Wyss $K$, Wångdahl $A$, Vesterlund $M$, Hammar $U$, Dashti $S$, Naucler $\mathrm{P}$, et al. Obesity and diabetes as risk factors for severe Plasmodium falciparum malaria: Results from a Swedish Nationwide study. Clin Infect Dis. 2017;65(6):949-58. https://doi. org/10.1093/cid/cix437

PMid:28510633

18. Ranson H, Edi CV, Koudou BG, Jones CM, Weetman D. Multipleinsecticide resistance in Anopheles gambiae mosquitoes Southern cote d'ivoire. Emerg Infect Dis. 2012;18(9):1508-1511. https://doi.org/10.3201/eid1809.120262

PMid:22932478

19. Nurcandra, F. Association of aerosol pesticide exposure to farmer lung function in Purworejo 2016 [Thesis on the internet]. Department of Epidemiology, faculty of Public Health: Universitas Indonesia. Available form: http://lib.ui.ac.id/ detail?id=20432677\&lokasi=lokal\#parentHorizontalTab2. [Last Accessed on 2016 Nov 2].

20. Yadouleton AW, Asidi A, Djouaka RF, Braïma J, Agossou CD, Akogbeto MC. Development of vegetable farming: A cause of the emergence of insecticide resistance in populations of Anopheles gambiae in urban areas of Benin. Malar J. 2009;8:103. https:// doi.org/10.1186/1475-2875-8-103

PMid: 19442297

21. Reid MC, McKenzie FE. The contribution of agricultural insecticide use to increasing insecticide resistance in African malaria vectors. Malar J. 2016;15:107. https://doi.org/10.1186/s12936-016-1162-4 PMid:26895980

22. Philbert A, Lyantagaye SL, Nkwengulila G. A review of agricultural pesticides use and the selection for resistance to insecticides in malaria vectors. Sci Res. 2014;2:120-8. https:// doi.org/10.4236/ae.2014.23019

23. Webber R. Communicable Diseases: A Global Perspective. $4^{\text {th }}$ ed. United Kingdom: CABI; 2012.

24. Prada-Arismendy J, Castellanos JE. Real time PCR. Application in dengue studies. Colomb Med. 2011;42(2013):243-58. Available from: http://www.bioline.org.br/pdf?rc11033. https:// doi.org/10.25100/cm.v42i2.778. [Last accessed on 2017 May 6]

25. Hamid PH, Ninditya VI, Prastowo J, Haryanto A, Taubert A, Hermosilla C. Current status of aedes aegypti insecticide resistance development from Banjarmasin, Kalimantan, Indonesia. Biomed Res Int. 2018;2018:1735358. https://doi.org/10.1155/2018/1735358 PMid:30671445

26. Mint Mohamed Lemine A, Ould Lemrabott MA, Niang EHA, Basco LK, Bogreau H, Faye O, et al. Pyrethroid resistance in the major malaria vector Anopheles arabiensis in Nouakchott, Mauritania. Parasit Vectors. 2018;11(1):344. https://doi. org/10.1186/s13071-018-2923-4

PMid:29895314

27. Jayaraj R, Megha P, Sreedev P. Organochlorine pesticides, their toxic effects on living organisms and their fate in the environment. Interdiscip Toxicol. 2016;9(3-4):90-100. https:// doi.org/10.1515/intox-2016-0012

PMid:28652852

28. van den Berg H, Zaim M, Yadav RS, Soares A, Ameneshewa B, Mnzava $A$, et al. Global trends in the use of insecticides to control vector-borne diseases. Environ Health Perspect. 2012;120(4):577-82. https://doi.org/10.1289/ehp.1104340 PMid:22251458

29. Zhu F, Lavine L, O'Neal S, Lavine M, Foss C, Walsh D. Insecticide resistance and management strategies in urban ecosystems. Insects. 2016;7(1):E2. https://doi.org/10.3390/insects7010002 PMid:26751480

30. Ondeto BM, Nyundo C, Kamau L, Muriu SM, Mwangangi JM, Njagi $\mathrm{K}$, et al. Current status of insecticide resistance among malaria vectors in Kenya. Parasit Vectors. 2017;10(1):429. https://doi.org/10.1186/s13071-017-2361-8 PMid:28927428

31. Silva AP, Santos JM, Martins AJ. Mutations in the voltage-gated sodium channel gene of anophelines and their association with resistance to pyrethroids-a review. Parasit Vectors. 2014;7:450. https://doi.org/10.1186/1756-3305-7-450 PMid:25292318

32. Keïta M, Traoré S, Sogoba N, Dicko AM, Coulibaly B, Sacko A, et al. Susceptibility status of Anopheles gambiae sensu lato to insecticides commonly used for malaria control in Mali. Bull Soc Pathol Exot. 2016;109(1):39-45. https://doi.org/10.1007/s13149-015-0461-2 PMid:26740098

33. Gorouhi MA, Oshaghi MA, Vatandoost H, Enayati AA, Raeisi A Abai MR, et al. Biochemical basis of cyfluthrin and DDT resistance in anopheles stephensi (Diptera: Culicidae) in malarious area of Iran. J Arthropod Borne Dis. 2018;12(3):310320. https://doi.org/10.18502/jad.v12i3.82 PMid:30584554

34. .Dang K, Doggett SL, Veera Singham G, Lee CY. Insecticide resistance and resistance mechanisms in bed bugs, Cimex spp. (Hemiptera: Cimicidae). Parasit Vectors. 2017;10(1):318. https://doi.org/10.1186/s13071-017-2232-3

PMid:28662724

35. Wang TN, Lin MC, Wu CC, Leung SY, Huang MS, Chuang HY, et al. Risks of exposure to occupational asthmogens in atopic and nonatopic asthma a case-control study in Taiwan. Am J Respir Crit Care Med. 2010;182(11):1369-1376. https://doi. org/10.1164/rccm.200906-0969oc

PMid:20639444 